\title{
Between a hermitage and a hospital
}

\author{
Cite as: CMAJ 2018 November 5;190:E1308-9. doi: 10.1503/cmaj.180552
}

CMAJ Podcasts: audio reading at https://soundcloud.com/cmajpodcasts/180552-enc

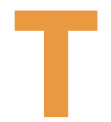

he road that led to the Kullu Valley Hospital was shaded by many deodar trees, which flourished in these parts of the Himalayas. Birds chirped and hid in their gnarly recesses. On some days, wind would unleash a spiral of cones and sticky needles from the treetops onto the road below, where they would catch on passing boots and bare feet and rickety rickshaws. Deodar, in Sanskrit, means wood of the gods, and many of the locals believed the trees were sacred. Cutting one down was punishable by law and for good reason: the trees anchored down the earth, so that it would not cascade in the form of a mudslide into the small, unfortified valley below.

In Kullu Valley, a place where mysticism runs as deep as the tree's roots, the sacred deodars were protectors of the people.

I had come to this valley in northern India to do an observership at the local hospital. Kullu was the place of my birth, but much had changed since I had left. Construction agencies had torn the valley apart to allow the narrow bazaar to expand, and the newly built Kullu Valley Hospital was the jewel of their effort: it was a truly modern building. The locals did not take kindly to it. Birds and monkeys shrieked in the woods on either side, a reminder that the hospital's presence here was an intrusion. It was a box of bright surfaces sitting in a garden of ancient trees: a piece of modernity flung so far back in time that it had gotten stuck there, among wood and moss.

The hospital's physicians were a silent, moustached, smoking bunch of middleaged men. They included an orthopedist, a pediatrician, an internist, a general surgeon and an obstetrician. The internist was my primary preceptor. He spoke in measured tones and moved with great

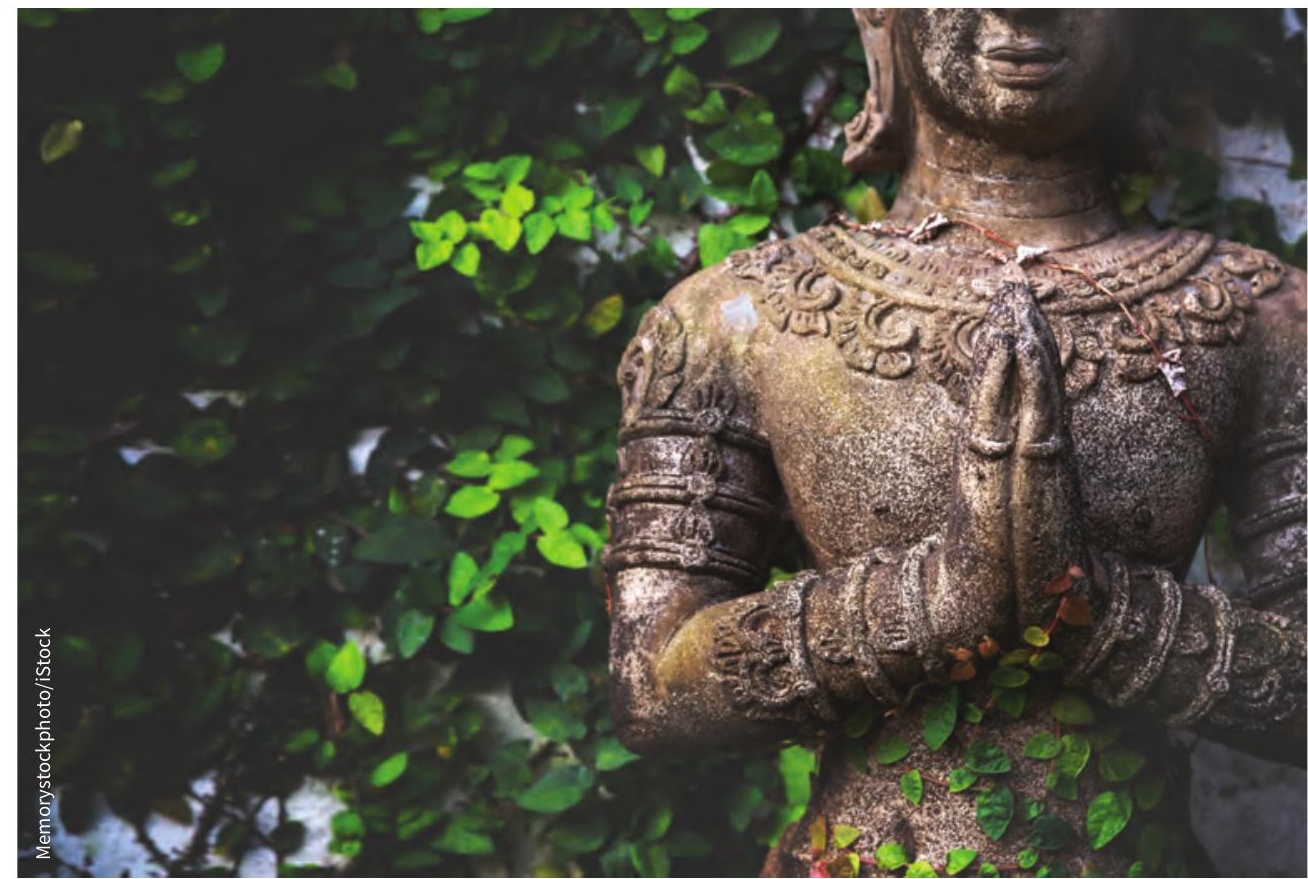

purpose, as if something in the air had touched upon a capacity for the profound. Patients came to him from all parts of the valley, and he, in turn, worked hard to see them all. On some nights, he stayed as late as 2 am, rounding on the inpatients as they drifted through fitful sleep, a whitecoated enigma on a dark hospital ward.

The same road that led to the Kullu Valley Hospital also passed by an ashram or spiritual hermitage. The ashram was a verdant building surrounded by trees, with an open amphitheatre reminiscent of the crumbling edifices of Athens. It was a quiet place, as native to the valley as the hospital was foreign, and full of reverence for some departed god. Its leader was the swami or spiritual guru. His disciples came from all parts of the valley. Silverhaired and stoic, he sat upon a chair carved from deodar wood and lectured to the amphitheatre crowds like an ancient messenger. Every day he would speak on a different topic, and the people would listen with undivided attention.

"To be truly open to this life," said the swami, sitting atop his chair of polished wood, "you must dare to confront the creeds that diminish other ways of living."

The internist paid the swami a respectful nod (and put out his cigarette) whenever he passed by him at the ashram. And the swami, in turn, bowed down to the internist, his knee-length beard touching the ground. Sometimes they spoke about life in the valley and the changing seasons, but more often they parted ways after a brief acknowledgement. Ensconced in their separate missions - to heal and to illuminate - they shared little in common. The internist rarely opened up about his beliefs, and yet his purposeful absence from the ashram attested to a certain lack of spiritual interest. 
Much later, after one of these encounters with the swami, my preceptor finally clarified his stance on the subject of belief:

"To witness a human body unravel in the many ways it can, is to be denied some of the solace that mysticism can provide. The only relief I desire is that which the creed of empiricism can offer."

He was, I noted with irony, preaching in the wrong place. Kullu Valley was deeply immersed in the occult. Holy gatherings took place everywhere: in temples, on the streets, in public bazaars. The many sounds of puja, or prayer, never failed to unite gatherers in the worship of some god or another. And those gods - Krishna, Ganesh, Hanuman - peered out from every shop, school and taxi, ready to receive whatever devotion the people had to offer. All around, deodars fell. The winds passed on. But spirituality was a constant, the one thing that never changed. In a valley that was being eroded by rivers and flattened one purposeful detonation at a time to make room for more hotels and ski lodges, only that belief in mysticism stayed as true as ever.

But the internist had a reason not to buy into that belief. He had seen its downside. Too often, patients put their faith in a god or a spiritual potion over a doctor or a proven treatment. They waited for hours, days, sometimes weeks, before coming to the hospital, ghostly pale from whatever sickness they had attempted to cure at home. And my preceptor grew frustrated. Who could ignore the signs of illness that neither a prayer nor a potion, however earnestly sung or swallowed, had modified in the least?

The power of that faith, however, could not be denied. Every morning, while the sun had not yet cleared the mountain peaks, the swami would rise from his bed and see the people of the valley, who came to seek his private blessing. It was an ashram ritual. In his holy company, compelled by a faith sturdier than the deodar, his disciples would make a confession. They would plead for his guidance. Or, they would ask him to perform a miracle.

One morning, I was told about a man who had arrived at the ashram door wrapped in a cocoon of hastily arranged shawls. A young woman was with him. The swami welcomed them in, but he looked worried: the man was in terrible shape. His whole body shook as if hijacked by some perverse entity. Rigors. I later learned that he was septic from a widely disseminated infection. But his wife thought he was suffering from some kind of black magic:

"My husband has become possessed! O swami, help him!"

The swami surveyed the woman. He surveyed the man. And the swami, knowing the limits of his mysticism, said, "seek help from where it is most likely to come."

He directed them to the Kullu Valley Hospital, now speckled with sunlight and dust from passing cars. The man and woman prostrated before their guru. If that was the swami's command, then that is what they would do.

The hospital's emergency room was already crowded with people, but the couple's entry caught the attention of my preceptor, who was attending to another patient. Seeing the husband's pale visage, he dropped the intravenous line he was placing and rushed across the room. The patient's wife was sobbing:

"Doctor, my husband is possessed! We have prayed to Dhanvantari, the god of health. We have used herbs. We have used the most sacred potions. It has been days, but he has only worsened!"

My preceptor's face hardened. His eyes narrowed. He was normally a compassionate man, filled with sympathy. Colleagues and patients knew that. They recommended him to others based on it. He understood what many others did not: that this life, with its sickness and turmoil, was a desperate thing. People believed in their tonics and potions. They trusted in their cancer-curing plants and diseaseridding herbs. But to swear by these things was to lose some of my preceptor's trust. It was to trade his sympathy for his suspicions.

But that cynicism would not prevail today. As my preceptor watched the couple in the emergency room, desperately seeking refuge in the things they knew best, he was reminded of what the swami had once said, long ago, in a voice that echoed through the amphitheatre and carried into the streets:

"We are all believers in one creed or another, hoping to be understood by those unlike ourselves."

And his shoulders loosened. His body finally relaxed. Facing the grief-stricken wife, he laid to rest his indignation, so that he could join his palms together and invite her into a prayer.

\section{Shaurya Taran MD}

Division of Internal Medicine, Department of Medicine, University of Toronto, Toronto, Ont.

This article has been peer reviewed.

The preceptor has given his consent for this story to be told. The case described is anonymized. 